\title{
Työ hyvinvoinnin uhkana?
}

Petteri Pietikäinen (toim. 2011). Työstä, jousta ja jaksa. Työn ja hyvinvoinnin tulevaisuus. Helsinki: Gaudeamus. 187 sivua.
KAHDEKSAN VUOTTA sitten ilmestynyt Juha Siltalan Työelämän huonontumisen lyhyt historia on merkittävin työelämän laadusta käytyä keskustelua virittänyt ja sävyttänyt merkkipaalu 2000-luvulla. Elinkeinoelämän Valtuuskunta EVAja Elinkeinoelämän keskusliitto EK ovat kampanjoineet Siltalan laajalle levinneitä näkemyksiä vastaan tuottamalla omaa, toista todistavaa tutkimusta. Työelämässä tapahtuu monensuuntaista muutosta, ja tutkimustuloksia voidaan tulkita useammalla tavalla. Tekijöiden kokemukset työstään ovat ensiarvoisen tärkeitä, koska niillä on välitön vaikutus tekemiseen ja työn jälkeen, eli laatuun. Kokemukset ovat myös olennainen osa yksilön hyvinvoinnin perustaa. Koettu hyvinvointi heijastuu niin ikään objektiivisissa indikaattoreissa ja esimerkiksi sairastavuudessa ja poissaoloissa, jotka puolestaan näkyvät kansantaloudenkin tasolla.

Työstä, jousta ja jaksa -kirjaan on koottu tuoretta tutkimustietoa työssä jaksamisesta ja työhyvinvoinnista. Kirjoittajia on lähemmäs viisikymmentä, useimmat Työterveyslaitokselta tai Terveyden ja hyvinvoinnin laitokselta. Kirjoittajina on joukko ansioituneita professoreita ja dosentteja työelämän ja terveystutkimuksen aloilta (esimerkiksi Marko Elo- vainio, Eero Lahelma, Pekka Martikainen, Jouko Nätti, Ossi Rahkonen, Minna Salmi). Artikkelit ovat lyhyitä ja ytimekkäitä. Kirjan toimittaja, Oulun yliopiston aateja oppihistorian professori Petteri Pietikäinen linjaa kokoelman otetta muutamalla väittämällä:

- masennuksen raju yleistyminen on kiistatta yhteydessä työelämän ongelmiin,

- määräaikainen työ vaikeuttaa pahasti yksilöiden ja perheiden elämänhallintaa,

- Suomi on luokkayhteiskunta, mistä todistaa esimerkiksi väestöryhmien terveyserot: mitä matalampi luokka-asema, sitä huonompi terveys ja lyhyempi elämä; eri luokkiin kuuluvien elinajan erot ovat Suomessa kasvaneet.

Ajatus siitä, että palkkatyössä voisi viihtyä tai että työ voisi tuottaa myös subjektiivista hyvinvointia, on työn historiassa aika uusi. Mutta kun ihmisen akuutit perustarpeet alkavat olla kohtuullisen hyvin tyydytettyjä, työssä jaksamiseen ja työhyvinvointiin on syytä kiinnittää aiempaa enemmän huomiota, mikäli ihmiset halutaan pitää töissä: "kaikkia ei saada viihtymään työssään kaiken aikaa, mutta (melkein) kaikki voidaan saada viihtymään työssään jonkin aikaa, ja jotkut voidaan saada viihtymään työssään (lähes) kaiken aikaa” (s. 17).

\section{EPÄVARMUUS EI LUO VIIHTYVYYTTÄ}

Ihmisiltä tuskin puuttuu halua viihtyä töissä ja lisätä työviihtyvyyttä, mutta määräaikaisten työsuhteiden, pätkä- ja silpputöiden vuoksi se on tehty todella vaikeaksi. Määräaikainen työ on Suomessa yleisempää kuin Euroopassa keskimäärin. Epävarmuus ei ylläpidä viihtyvyyttä. Runsas sijaisten ja määräaikaisten käyttö ei koettele vain pätkätyöläisiä itseään vaan kuormittaa myös vakituista henkilöstöä. Esimerkiksi naisvaltaisella hoitoalalla vakituisella henkilöstöllä on selvemmin vaikeuksia työn kuormittavuuden kanssa kuin määräaikaisilla. Vakituiset ovat stressaantuneempia ja käyvät useammin myös sairaana töissä. Epävarmuudella ja epätyypillisillä työajoilla on selvä yhteys heikkoon työhönsitoutumiseen, joka taas kiihdyttää henkilöstön vaihtuvuutta ja heikentää esimerkiksi hoiva- ja palvelualoilla laatua.

Määräaikaisuus on ilmeisesti tullut jäädäkseen, ja siihen on alettu jossain määrin myös tottua. Kun vakituiset työsuhteet muuttuvat enenevästi määräaikaisiksi, psykologiseksi sopimukseksikin nimetty vaihtosuhde palkansaajan ja työnantajan välillä muuttuu. Ennen muuta psykologisen sopimuksen muutos näkyy lojaa- 
lisuuden ja sitoutumisen vähenemisenä niin työnantajan kuin työntekijän puolelta. Työntekijä ei enää oletakaan työnantajan olevan kiinnostunut hänen hyvinvoinnistaan, tyytyväisyydestään viihtyvyydestään. Tämä saattaa jopa vapauttaa pätkätyötä tekevää stressistä, koska hänen ei kannata panostaa työhön, joka on kuitenkin vain väliaikaista. Palkkapäivää odottaessaan hän hoitaa hommansa vähän kuin vasemmalla kädellä työn laadusta murehtimatta.

Vielä 1950-luvulla enemmistö suomalaista työskenteli fyysisesti raskaissa maatalous- ja tehdastöissä. Onko niin, että työn 'henkistyessä' ruumiillisesti raskas työ on kadonnut, kirjassa kysytään. Nykyisin työ on käynyt fyysisesti raskaaksi ammateissa, joita ei aiemmin pidetty kovin rasittavina. Näitä on lisääntyvässä määrin esimerkiksi naisvaltaisella sosiaali- ja terveydenhuoltoalalla. Sukupuoli ja luokka-asema ovat keskeisiä työn kuormittavuudessa. Työn fyysinen kuormittavuus yksipuolisesti toistuvine liikkeineen ja huonoine työasentoineen on odotettua yleisempää ja jopa lisääntynyt 2000-luvulle tultaessa. Kirjoittajat pohtivat myös syitä siihen, että fyysisen kuormittavuuden tutkimus on jäänyt niin vähäiseksi. Muotoaan muuttanutta fyysisesti raskasta työtä ei enää tunneta riittävän hyvin.

\section{LUOKKAEROT NÄKYVÄT TYÖKYVYTTÖMYYSLUVUISSA}

Luokkaerot näkyvät työn kuormittavuuden lisäksi esimerkiksi eriarvoisuutena työkyvyttömyyseläkkeelle siirtymisessä. Vaikka työkyvyttömyyseläkkeelle jäädään 2000-luvulla kaikissa yhteiskuntaluokissa harvemmin kuin ennen 1990-luvun lamaa, luokkien suhteelliset erot ovat jopa aiempaa suuremmat. Työkyvyttömyys ja syrjäytyminen lankeavat ennen muita työväestön kannettavaksi. Työkyvyttömyyseläkkeellä on noin kahdeksan prosenttia työikäisestä väestöstä eli reilut neljännesmiljoona kansalaista, mikä ei ole vähäpätöinen asia kansantaloudellisesti, puhumattakaan yksilöitä ja heidän lähipiiriään koettelevista kokemuksista. Suurimpina syinä työkyvyttömyyteen ovat tuki- ja liikuntaelinsairaudet sekä järkkynyt mielenterveys. Luokkaerot ovat suurimmillaan tuki- ja liikuntaelinsairauksissa. Työläisten riski joutua/päästä työkyvyttömyyseläkkeelle tuki- ja liikuntaelinsairauksien vuoksi on jopa viisitoistakertainen ylempiin toimihenkilöihin verrattuna. Fyysisten työolojen vaikutusta työntekijöiden hyvinvointiin tunnutaan nykyään yleisesti aliarvioitavan.

Muitakin mielenkiintoisia (ja työn ulkopuolelle levittyviä) ana- lyysejä kirjasta löytyy: esimerkiksi se, miten liikuntatottumukset ovat yhteydessä työoloihin ja luokkaasemaan. Suurituloiset ja korkeasti koulutetut liikkuvat enemmän kuin pienituloiset ja vähän koulutetut. Liikunta on merkittävää työssä jaksamisen kannalta: liikuntaa harrastavat kokevat vähemmän työstressiä, ja liikunta suojaa eritoten naisia stressin aiheuttamalta masennukselta. Tutkijat tiivistävät tuloksiaan toteamukseen: "vapaaajan liikunta-aktiivisuutta eivät selitä ainoastaan yksilöiden ominaisuudet tai elämänvaiheet, vaan taustalla vaikuttavat yhteiskunnalliset rakenteet" (s.68).

Kun yhä useamman on epätodennäköistä saada itselleen vakituista työsuhdetta, työntekijäpuolen olisi joukolla syytä vaatia ponnekkaammin tiettyjä etuja määräaikaisessakin työssä. Työnantajat pitäisi painostaa järjestämään määräaikaisillekin kehittymismahdollisuuksia ja koulutusta - ja vieläpä sellaista koulutusta, josta on hyötyä työelämässä laajemmin kuin yhdessä yrityksessä. Työnantajat pitäisi saada (yksin tai yhdessä julkisen vallan kanssa) järjestämään sellaista koulutusta, joka parantaa määäaikaisen työntekijän mahdollisuuksia löytää itselleen uusi, ja kenties parempi ja turvatumpi, työ. Tämä on mielestäni kirjan yksi tärkeimpiä johtopää- 
töksiä. Tutkimus nimittäin osoittaa, että mitä vahvemmaksi pätkätyöntekijä arvioi omat mahdollisuutensa työllistyä työttömäksi jäädessään, sitä vähemmän hän kokee stressiä ja uupumusta. Työllistymisusko on yksilölle voimavara, jota voidaan vahvistaa yhteiskuntapoliittisilla toimilla. Mutta epäilemättä prekariaatin työmarkkina-aseman parantamiseksi tarvitaan ammattiyhdistysliikettä. Työnantajat eivät omatoimisesti ryhdy ajamaan pätkätyöläisten asiaa.
Kirjan tutkimukset ovat peräisin Suomen Akatemian vuosina 2007-2010 toteuttaman Työn ja hyvinvoinnin tulevaisuus -tutkimusohjelman hankkeista. Kirja aloittaa Gaudeamuksen ja Suomen Akatemian Tutkitusti-kirjasarjan, joka esittelee Akatemian tutkimusohjelmien tuloksia korkeakouluyhteisöä laajemmalle lukijakunnalle, tarkoituksena herätellä keskustelua ajankohtaisista yhteiskunnallisista epäkohdista. Kirja on pienen kokonsa vuok- si hyvää matkaseuraa niille, jotka haluavat perehtyä ajankohtaisiin teemoihin sanoma- ja iltapäivälehtijuttuja perusteellisemmin. Kohtuuhintaisena tällaisen voisi napata matkalle mukaan rautatieja lentoasemalta, jos näitä olisi siellä tarjolla.

Heikki Silvennoinen päätoimittaja, professori 